\title{
The Reactions over Organizational Citizenship Behavior (OCB) that viewed from Transformational Leadership, Organizational Culture, and Compensation Variables
}

\author{
Rr. Diana Candra Hapsari \\ Master of Management Student, Mercu Buana University \\ Jakarta, Indonesia
}

\begin{abstract}
This research intends to discover the level of influence of transformational leadership, organizational culture, and compensation systems on Organizational Citizenship Behavior (OCB) within the Judicial Commission officers. Those respondents in this research were amount 130 employees of the Judicial Commission who were civil servants. The technique of data collection is done by meeting respondents directly and distributing questionnaires to employees. Data have been scrutinized by Statistical Package for Social Sciences (SPSS) version 25.0. The analysis shows that transformational leadership significantly influences $\mathrm{OCB}$, organizational culture significantly affects $O C B$, and compensation significantly influences OCB. Simultaneously leadership, organizational culture, and compensation significantly impact OCB. This result also shows that organizational culture is the dominant variable and influence on OCB within the Judicial Commission employees.
\end{abstract}

Keywords:- Transformational Leadership, Organizational Culture, Compensation, Organizational Citizenship Behavior.

\section{INTRODUCTION}

Law No.25 of 2009 mandates that public service delivery organizations are obliged to provide public services following the objectives of forming and conducting evaluations of the performance of implementers in the organization's environment on a regular and ongoing basis. The Judicial Commission, as a state institution, also a public service organization, has conducted a continuous performance evaluation through the measurement of its primary services from 2015 to 2018. Based on Permenpan RB No. 14 of 2017, the results of the service performance of the Judicial Commission is still in the intimate 65.00 76.60 with the predicate of "C" quality or "poor" service performance. It means there are still 0.5 points that must be pursued by the Judicial Commission to obtain the title of 'good' service performance. Organizational performance improvement also influences the quality of the behavior of members of the organization. Where this behavior is not only shown by the quality of work performance (performance) by the tasks that have been carried out but also requires other actions that are shown by employees

\author{
Setyo Riyanto \\ Associate Professor Mercu Buana Universitay \\ Jakarta, Indonesia
}

who gave that positive contribution to the organization. The success of the organization will achieve if the employees not only their basic tasks but also do extra jobs.

Behaviors and additional work actions that exceed the description of the roles specified in the organization are the basic concepts of Organizational Citizenship Behavior (OCB). OCB one of a tool that could identify that behavior from employees who want to contribute to exceeding the demands of the role at work. Therefore, to improve the value of the Judicial Commission's service performance, employees who have good OCB are needed. However, the results of the survey revealed that the OCB percentage of employees of the Judicial Commission was in a low category. And from the effects of interviews with several structural officials and employees of the Judicial Commission, it was found that the factors that influenced OCB were transformational leadership, organizational culture, and compensation. Therefore in this research has given more attention to those reactions from transformational leadership, organizational culture, and settlement on OCB within the Judicial Commission employees of the Republic of Indonesia.

\section{LITERATURE REVIEW}

\section{A. Transformational Leadership}

Robbins and Judge (2015: 249) argue that leadership is the capacity to give affection to a group in achieving a vision or set of targets. The same thing was stated by Stogdill in Iis Kartini (2017:77) that leadership is the ability to influence others in getting things done.

Bass in Mamesah and Kusmaningtyas (2009) suggested that transformational leadership is the influence of leaders or superiors on subordinates. Subordinates would felt reliance, honor, allegiance, and respect for superiors and would prompt to do extra miles. As for the dimensions of transformational leadership, as follows (Bass, 2008):

Idealized influence, a leader behaves as a model for his subordinates, usually respected and trusted, tends to be charismatic, through the formulation of a clear vision and mission, obtaining support and trust from subordinates/members of the organization and colleagues. 
Inspirational Motivation, leaders behave to motivate with inspiration to the people around them, communicate high expectations, using slogans to focus efforts to express something important simply.

$>$ Intellectual Stimulation, the leader stimulates the efforts of his subordinates to apply innovative and creative, limiting problems and approaches from old situations in new ways, promoting the use of intelligence, prioritizing rationality, and conducting problem-solving carefully.

$>$ Individual Consideration, leaders have exceptional attention to the needs of individuals in achieving and the growth they expect to behave as a coach or mentor and provide advice.

\section{B. Organizational Culture}

Robbins and Coulter (2016:84) argue that organizational culture is the values, concept, costumes, and style of work which give out by each member of the organization and influences the way members to behave as well as being a differentiator with other organizations. According to Susanto in Sudaryono (2014:36), organizational culture is the values that hold by human resources in accomplishing their commitment and act within the organization. Those merits will respond to whether that action is right or wrong or whether a behavior was approved to do so it could serve as a foundation for behavior.

According to Robbins and Coulter (2016:85), there are seven dimensions of organizational culture, namely:

$>$ Innovation and daring to take those risks (Innovation and risk-taking), is the extent to which the organization encourages employees to be innovative and dare to take risks.

$>$ Attention to detail (attention to detail), how far which employees are expected to show the position of accuracy, analysis, and attention to detail.

$>$ Results-oriented (outcome orientation), is how far which management decisions focus on results, not on technical or process of achieving those results.

$>$ People-oriented is the extent to which management decisions take into account the effects of results on people in the organization.

$>$ People-oriented is the further details regards management decisions take into account the effects of results on people in the organization.

$>$ Team oriented, is further seen towards work activities are organized around teams and not individually.

$>$ Aggressiveness (aggressive) is the further viewed towards people in the organization who are aggressive and competitive to run the organizational culture as well as possible.

$>$ Stability (stability) is further viewed in which the organization's activities emphasize the status quo (maintaining what is there because it is considered good enough) rather than growth.

\section{Compensation}

Compensation is the rights that must be received by employees in return after they carry out their obligations in return for their work (Sutrisno, 2014:197). According to Sigit in Tampi (2013), compensation is any form of compensation given by the company to employees for the award received by the employee concerned. This opinion is almost similar to Dessler (2015: 417) states that all forms of payment are given to employees and arising from the work they do.

According to Hasibuan (2014: 119), compensation is the provision of direct or indirect compensation, money, or goods to employees in return for services provided by the company.

Simamora's opinion (2010: 442) is not much different from stating that compensation is a financial and nonfinancial reward received by an employee from a company as compensation for an employee's service. Simamora (2010: 448) states that benefit is divided into two dimensions, namely:

$>$ Direct Compensation. Compensation in the form of money is carried out directly, as a reward to employees who devote their energy to the company or organization. This payment can be in the form of salary, commission, and bonus

$>$ Indirect compensation. Compensation is paid indirectly by being paid to employees who have given their energy to the company or organization, usually, in the form of benefits and facilities.

\section{Organizational Citizenship Behavior}

Robbins and Judge in Waspodo (2012) stated that organizational citizenship behavior (OCB) as a chosen act which not a piece of an employee's formal work commitments but supports an effective purpose to organization. According to Organ in Budiharjo (2011:182), organizational citizenship behavior (OCB) is an individual voluntary behavior (in this case, employees) that is not directly related to the rewarding system but contributes to the effectiveness of the organization. In other words, organizational citizenship behavior (OCB) is the behavior of an employee not because of the demands of his task but rather based on volunteerism.

The dimensions of organizational citizenship behavior (OCB) that are widely known and used in research are the dimensions of organizational citizenship behavior (OCB) proposed by Organs in Danendra and Mujiati (2016) consisting of:

$>$ Altruism, the voluntary act from employees in helping their colleagues who shared difficulties in the situation that is being faced between tasks in the organization and other people's personal problems. This means giving help that is not an obligation that is borne.

$>$ Courtesy, maintaining good relations with coworkers to evade interpersonal problems. Someone who has that dimension is someone whom respects also cares for others. 
Sportsmanship, act that tolerates less than ideal conditions in an organization without raising objections. Someone who has a high level in this dimension will increase a positive climate among employees. Employees will be more polite and cooperate with others so that it will create a more pleasant work environment.

$>$ Civic virtue, behavior that indicates responsibility for organizational life. This dimension affects the responsibility given by an organization to a person to improve the quality of the occupations that are occupied.

$>$ Conscientiousness, behavior that is shown by trying to exceed what is expected by the company. Voluntary behavior that is not an employee's obligation or duty. This dimension reaches far above and far ahead of the call of duty.

\section{E. Previous Research}

Several previous studies have discussed the effects of transformational leadership, organizational culture, and compensation on OCB. Vina et al. (2018) transformational leadership had a strong reaction towards OCB; Sobihah et al. (2017) showed that organizational culture was a proven strong positive Connection with OCB, Danendra, and Mujiati (2016) showed that compensation had a positive effect and significant to OCB.

\section{F. Framework}

Based on the literature review and prior Research on the effect of work motivation, organizational commitment, and job satisfaction on employee performance, researchers developed the following models:

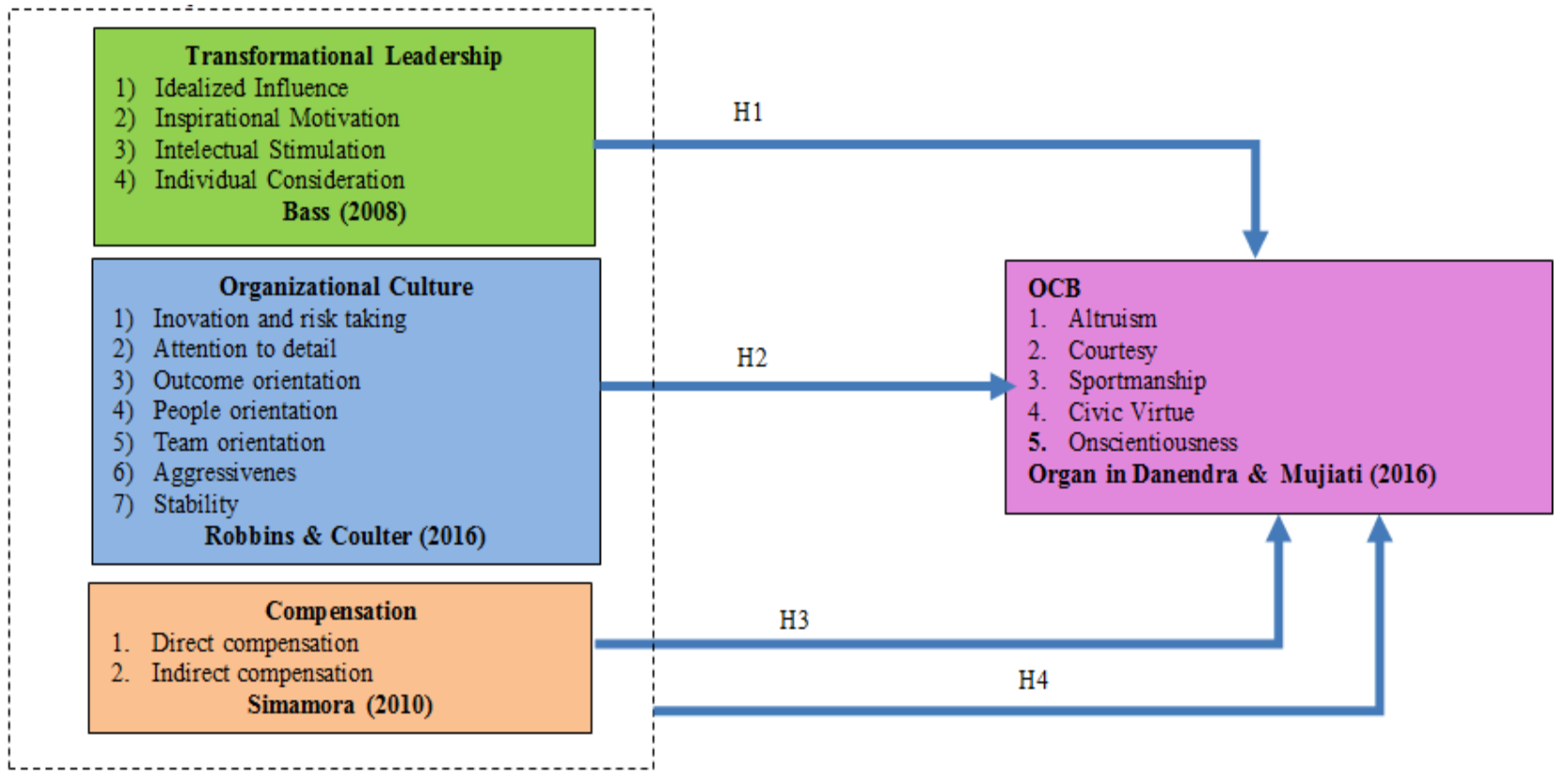

Fig 1:- Thinking framework

\section{G. Hypothesis}

According to that Framework, the hypothesis of this research could be formulated as follows:

H1: Transformational leadership has a positive and strongly reacted Towards OCB

$\mathrm{H} 2$ : Organizational Culture has a positive and strongly reacted towards OCB

$\mathrm{H} 3$ : Compensation has a positive and strongly React on OCB

H4: Leadership, Organizational Culture, and Co-Leadership have a positive and strongly Reacted on OCB

\section{METHODOLOGY}

\section{A. Population and Sample}

The population in this study were all Civil Servants in the Judicial Commission as many as 191 people, and the study sample was taken using a purposive random sampling technique with a total sample of 130 employees.

\section{B. Method of Collecting Data}

The method used in data collection in this study used a Likert scale technique in the form of a questionnaire. The statements in this questionnaire are favorable and unfavorable. Each statement has five alternative answers, namely: strongly agree, agree, disagree, disagree, strongly disagree.

\section{RESULTS AND DISCUSSION}

\section{A. Validity and Reliability Test Results}

Based on the results of the Validity Test, it can be seen that for OCB variables (Y), Leadership Transformation (X1), Organizational Culture (X2), and Compensation (X3) each question gets an $r$ count higher than $r$ tables. This means that all items in the questionnaire are valid. 
ISSN No:-2456-2165

\begin{tabular}{|c|c|c|c|c|}
\hline Variable & Number of Question & Value ranges (r count) & r table & Notes \\
\hline Transformational Leadership (X1) & 16 & $0,570-0,896$ & 0,172 & Valid \\
\hline Organizational Culture (X2) & 28 & $0,600-0,759$ & 0,172 & Valid \\
\hline Compensation (X3) & 12 & $0,444-0,717$ & 0,172 & Valid \\
\hline OCB (Y) & 20 & $0,441-0,677$ & 0,172 & Valid \\
\hline
\end{tabular}

Table 1:- The Result of Validity Test

Based on the results of the reliability test, it can be seen that the variables of Leadership (X1), Organizational Culture (X2), Work Compensation (X3), and OCB Variables (Y), have Cronbach's Alpha values of 0.957,
0.959, 0.799, and 0.901 and all are above 0 6. Thus the variables of Leadership (X1), Organizational Culture (X2), Work Compensation (X3), and OCB variables (Y) are declared reliable.

\begin{tabular}{|c|c|c|c|}
\hline Variables & Cronbach's Alpha count & Requirement & Notes \\
\hline Transformational Leadership (X1) & 0,957 & $>0.6$ & Reliable \\
\hline Organizational Culture (X2) & 0,959 & $>0.6$ & Reliable \\
\hline Compensation (X3) & 0,799 & $>0.6$ & Reliable \\
\hline OCB (Y) & 0,901 & $>0.6$ & Reliable \\
\hline
\end{tabular}

Table 2:- The Result of Reliability Test

\section{B. Normality Test}

The assumption of data normality on the histogram chart follows the normal line, and the data distribution on the normal P-plot plot is located around the diagonal line. While based on the Kolmogorov-Smirnov normality test, it is known that the Asymp value. Sig. (2-tailed) Unstandardized Residual of 0.200 is greater than 0.05 , so it can be concluded that the regression data in this study are normally distributed.

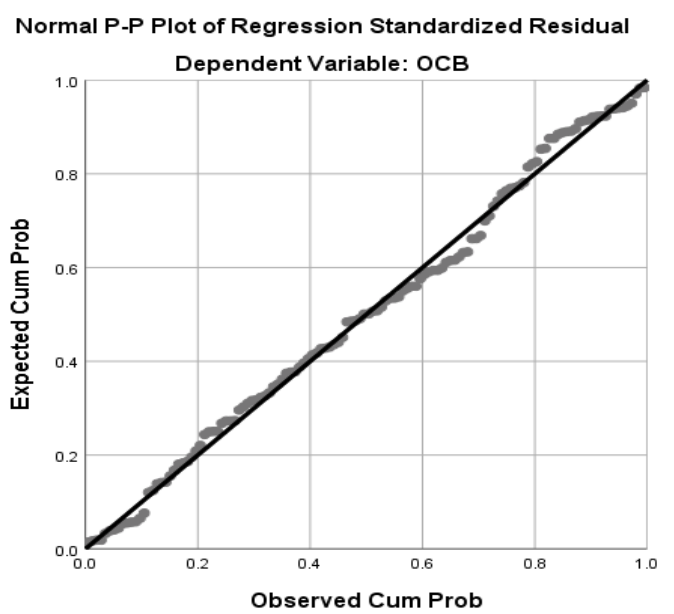

Fig 2:- The Result of Normality Test

\begin{tabular}{|c|c|c|}
\hline \multicolumn{3}{|c|}{ One-Sample Kolmogorov-Smirnov Test } \\
\hline \multicolumn{3}{|c|}{ Unstandardized Residual } \\
\hline \multicolumn{2}{|c|}{$\mathrm{N}$} & 130 \\
\hline \multirow{2}{*}{$\begin{array}{c}\text { Normal } \\
\text { Parameters }\end{array}$} & Mean & 0,0000000 \\
\cline { 2 - 3 } Most Extreme & Std. Deviation & 0,20312106 \\
\cline { 2 - 3 } Differences & Absolute & 0,054 \\
\cline { 2 - 3 } & Positive & 0,047 \\
\cline { 2 - 3 } & Negative & $-0,054$ \\
\hline \multicolumn{2}{|c|}{ Test Statistic } & 0,054 \\
\hline \multicolumn{2}{|c|}{ Asymp. Sig. (2-tailed) } & $.200^{\text {c,d }}$ \\
\hline
\end{tabular}

Table 3:- The Result of Normality Test

\section{Heteroscedasticity Test}

Based on the graph below, the points spread randomly above and below the number 0 on the y-axis, and do not have a clear pattern. Thus, it can be concluded that the regression model does not have heteroscedasticity.

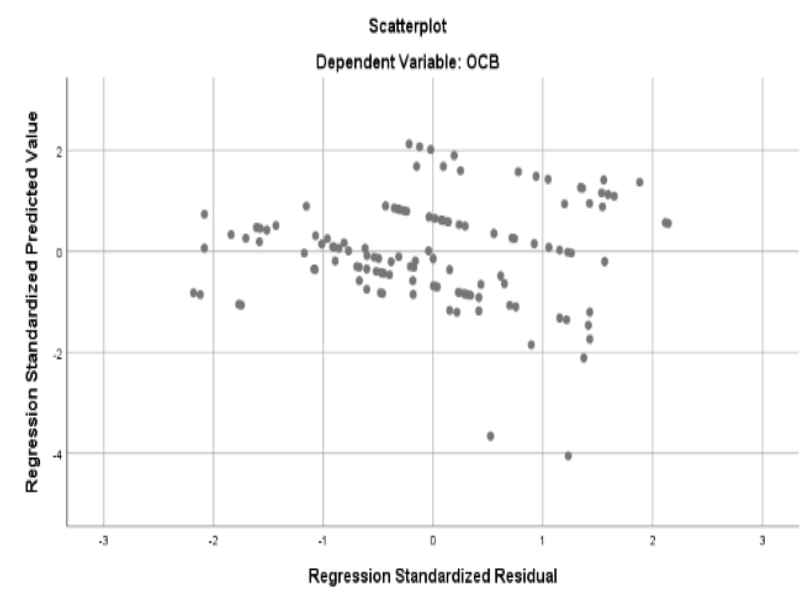

Fig 3:- Result of Heteroscedasticity

\section{Multicollinearity Test}

The results of Table 4, the tolerance value of each variable has a tolerance result above 0.10 , and a VIF value below 10. This means that there is no multicollinearity between transformational leadership variables, organizational culture, and compensation used in the search or research model.

\begin{tabular}{|c|c|c|}
\hline \multicolumn{3}{|c|}{ Coefficients } \\
\hline \multirow{2}{*}{ Model } & \multicolumn{2}{|c|}{ Collinearity Statistics } \\
\cline { 2 - 3 } & Tolerance & VIF \\
\hline (Constant) & & \\
\hline Transformational Leadership & 0.736 & 1.358 \\
\hline Organizational Culture & 0.774 & 1.291 \\
\hline Compensation & 0.812 & 1.232 \\
\hline
\end{tabular}

Table 4:- Result of Multicollinearity Test 
ISSN No:-2456-2165

\section{E. Multiple Linear Regression Analysis Test}

This test includes a classic assumption test with data requirements must be normally distributed; the model must be free from the symptoms of multicollinearity and free from heteroscedasticity.

\begin{tabular}{|c|c|c|c|c|c|}
\hline \multicolumn{6}{|c|}{ Coefficients } \\
\hline & \multirow{2}{*}{ Model } & \multicolumn{2}{|c|}{ Unstandardized Coefficients } & \multirow{2}{*}{$\mathbf{t}$} & \multirow{2}{*}{ Sig. } \\
\hline & & $\mathbf{B}$ & Std. Error & & \\
\hline \multirow{4}{*}{1} & (Constant) & 1.110 & 0.141 & 7.873 & 0.000 \\
\hline & Transformational Leadership & 0.330 & 0.031 & 10.699 & 0.000 \\
\hline & Organizational Culture & 0.228 & 0.036 & 6.307 & 0.000 \\
\hline & Compensation & 0.244 & 0.042 & 5.848 & 0.000 \\
\hline
\end{tabular}

Table 5:- Result of Multiple Regression Analysis

Results obtained:

$$
\mathrm{Y}=1,110+0,330 \mathrm{X} 1+0,228 \mathrm{X} 2+0,244 \mathrm{X} 3+\mathrm{e}
$$

This can be interpreted as follows:

Constant of 1.110; it can be interpreted that without transformational leadership variables, organizational culture, and compensation, the OCB value is 1.110 .

$>$ The leadership regression coefficient of 0.330 ; it can be interpreted that each transformational leadership is increased by 1 unit, then OCB will increase by 0.330 .

$>$ The regression coefficient for organizational culture variables is 0.228 ; it can be interpreted that each organizational culture is increased by 1 unit, then OCB will increase by 0.228 .

$>$ The regression coefficient of the compensation variable is 0.244; it can be interpreted that each compensation is increased by 1 unit, then OCB will increase by 0.244 .

\section{F. The t-test (partial)}

The t-test is used to determine the effect of partially independent variables on the dependent variable. T-test results for each independent variable can be seen in the table below.

\begin{tabular}{|c|c|c|c|c|c|}
\hline \multicolumn{6}{|c|}{ Coefficients } \\
\hline & \multirow{2}{*}{ Model } & \multicolumn{2}{|c|}{ Unstandardized Coefficients } & \multirow{2}{*}{$\mathbf{t}$} & \multirow{2}{*}{ Sig. } \\
\hline & & $\mathbf{B}$ & Std. Error & & \\
\hline \multirow{4}{*}{1} & (Constant) & 1.110 & 0.141 & 7.873 & 0.000 \\
\hline & Transformational Leadership & 0.330 & 0.031 & 10.699 & 0.000 \\
\hline & Organizational Culture & 0.228 & 0.036 & 6.307 & 0.000 \\
\hline & Compensation & 0.244 & 0.042 & 5.848 & 0.000 \\
\hline \multicolumn{3}{|c|}{ a. Dependent Variable: OCB } & & & \\
\hline
\end{tabular}

Table 6:- Result of t-test

Statistical test results show that the significant value for the influence of transformational leadership on OCB is $0,000>0.05$, and the value of $\mathrm{t}$ count $10.699>\mathrm{t}$ table 1.979 , so it can be concluded that $\mathrm{H} 1$ is accepted which means the influence of transformational leadership on OCB is positive and significant. The significant value for the influence of organizational culture on OCB is $0,000>0.05$, and the value of $\mathrm{t}$ count $6.307>1.979$, so it can be concluded that $\mathrm{H} 2$ is accepted, which means the influence of organizational culture on OCB is positive and significant. The significant value for the effect of compensation on OCB is $0,000>0.05$, and the value of $t$ arithmetic $5.848>1.979$, so it can be concluded that $\mathrm{H} 3$ is accepted, which means the compensation effect on OCB is positive and significant.

\section{G. Test Results $F$}

$\mathrm{F}$ Test results are used to determine the presence or absence of simultaneous influences (together) given independent variables on the dependent variable.

\begin{tabular}{|c|c|c|c|c|c|c|}
\hline \multicolumn{2}{|c|}{ ANOVA $^{\text {a }}$} \\
\hline \multirow{3}{*}{1} & Model & Sum of Squares & df & Mean Square & F & Sig. \\
\hline & Regression & 17.859 & 3 & 5.953 & 141.021 & $.000^{\mathrm{b}}$ \\
\cline { 2 - 7 } & Residual & 5.319 & 126 & 0.042 & & \\
\cline { 2 - 6 } & Total & 23.178 & 129 & & \\
\hline \multicolumn{6}{|c|}{ a. Dependent Variable: OCB } \\
\hline
\end{tabular}


From the table above it is known the significance value for the influence of transformational leadership, organizational culture and compensation on OCB are 0,000 $<0.05$ and $\mathrm{F}$ count $141,021>\mathrm{F}$ table 2,68 , so it can be concluded that $\mathrm{H} 4$ is accepted which means there is an influence of transformational leadership, organizational culture and simultaneous compensation to OCB.

\section{H. Determination Test $\left(R^{2}\right)$}

The coefficient determined determines what percentage of influence a given independent variable simultaneously has on the dependent variable.

\begin{tabular}{|c|c|c|c|c|}
\hline \multicolumn{5}{|c|}{ Model Summary $^{\mathbf{b}}$} \\
\hline Model & $\mathrm{R}$ & R Square & Adjusted R Square & Std. Error of the Estimate \\
\hline 1 & $.878^{\text {a }}$ & 0.771 & 0.765 & 0.205 \\
\hline \multicolumn{5}{|r|}{ b. Predictors: (Constant), Compensation, Organizational Culture, Transformational Leadership } \\
\hline \multicolumn{7}{|c|}{ b. Dependent Variable: OCB } \\
\hline
\end{tabular}

Table 8:- Result of Determination Coefficient Analysis $\left(\mathrm{R}^{2}\right)$

Based on the table above, the value of Adjusted $\mathrm{R}$ Square $=0.765$. This shows that $76.5 \%$ OCB $(\mathrm{Y})$ is influenced by the variables of Leadership (X1), Organizational Culture (X2), and Work Compensation (X3) while the rest $(100 \%-76.5 \%)$ is $23.5 \%$ OCB ( Y) was reactions towards other factors outside this research.

\section{Correlation Between Dimensions}

The correlation analysis of this study was conducted to identify the relationship between the dimensions of transformational leadership, organizational culture, and compensation for the OCB dimension. Correlation matrix between dimensions can be seen in the following table:

\begin{tabular}{|c|c|c|c|c|c|c|}
\hline \multicolumn{7}{|c|}{ Correlations } \\
\hline \multirow[b]{2}{*}{ Variable } & \multirow[b]{2}{*}{ Dimension } & \multicolumn{5}{|c|}{ OCB (Y) } \\
\hline & & $\begin{array}{c}4.1 \\
\text { Altruism }\end{array}$ & $\begin{array}{c}4.2 \\
\text { Concientiousness }\end{array}$ & $\begin{array}{c}4.3 \\
\text { Civic virtue }\end{array}$ & $\begin{array}{c}4.4 \\
\text { Sportsmanship }\end{array}$ & $\begin{array}{c}4.5 \\
\text { Courtesy }\end{array}$ \\
\hline \multirow{4}{*}{$\begin{array}{c}\text { Transformational } \\
\text { Leadership } \\
\left(\mathrm{X}_{1}\right)\end{array}$} & $\begin{array}{l}\text { 1.1 Idealized } \\
\text { Influence }\end{array}$ & 0.677 & 0.641 & 0.688 & 0.680 & 0.619 \\
\hline & $\begin{array}{c}1.2 \\
\text { Inspirational } \\
\text { Motivation }\end{array}$ & 0.640 & 0.617 & 0.646 & 0.654 & 0.618 \\
\hline & $\begin{array}{c}\text { 1.3 Intelectual } \\
\text { Stimulation }\end{array}$ & 0.644 & 0.622 & 0.632 & 0.631 & 0.624 \\
\hline & $\begin{array}{l}\text { 1.4 Individual } \\
\text { Consideration }\end{array}$ & 0.671 & 0.582 & 0.667 & 0.597 & 0.584 \\
\hline \multirow{7}{*}{$\begin{array}{l}\text { Organizational } \\
\text { Culture } \\
\left(\mathrm{X}_{2}\right)\end{array}$} & $\begin{array}{l}2.1 \text { Inovation } \\
\text { and risk taking }\end{array}$ & 0.427 & 0.485 & 0.483 & 0.460 & 0.444 \\
\hline & $\begin{array}{l}2.2 \text { Attention to } \\
\text { detail }\end{array}$ & 0.467 & 0.560 & 0.444 & 0.537 & 0.424 \\
\hline & $\begin{array}{l}2.3 \text { Outcome } \\
\text { orientation }\end{array}$ & 0.503 & 0.538 & 0.501 & 0.505 & 0.450 \\
\hline & $\begin{array}{l}2.4 \text { People } \\
\text { orientation }\end{array}$ & 0.509 & 0.527 & 0.512 & 0.530 & 0.494 \\
\hline & $\begin{array}{l}2.5 \text { Team } \\
\text { orientation }\end{array}$ & 0.511 & 0.541 & 0.520 & 0.520 & 0.518 \\
\hline & $\begin{array}{c}2.6 \\
\text { Aggressivenes }\end{array}$ & 0.491 & 0.538 & 0.509 & 0.551 & 0.511 \\
\hline & 2.7 Stability & 0.401 & 0.503 & 0.461 & 0.494 & 0.420 \\
\hline \multirow{2}{*}{$\begin{array}{l}\text { Compensation } \\
\qquad\left(\mathrm{X}_{3}\right)\end{array}$} & $\begin{array}{l}3.1 \text { Direct } \\
\text { compensation }\end{array}$ & 0.471 & 0.457 & 0.462 & 0.446 & 0.435 \\
\hline & $\begin{array}{l}3.2 \text { Indirect } \\
\text { compensation }\end{array}$ & 0.469 & 0.397 & 0.496 & 0.487 & 0.498 \\
\hline \multicolumn{2}{|c|}{$\mathrm{N}$} & 130 & 130 & 130 & 130 & 130 \\
\hline \multirow{2}{*}{\multicolumn{7}{|c|}{ **. Correlation is significant at the 0.01 level (2-tailed). }} \\
\hline & & & & 1 (2-tailed). & & \\
\hline
\end{tabular}

Table 9:- Result of Interdimensional Correlation 
The table above shows that the results of the dimension correlation matrix values between variables can be described that the highest correlation value between the dimensions in the Transformational Leadership (X1) variable to the $\mathrm{OCB}(\mathrm{Y})$ variable is the $\mathrm{X} 1.1$ Idealized Influence dimension with the $\mathrm{Y} 3$ dimension. Civic Virtue is 0.688 and is included in the category of strong relationship level. This explains that the dimension X1.1 Idealized Influence in the Leadership variable is needed to support the increase in OCB (Y), especially in the OCB Civic Virtue dimension. The highest correlation value between the Organizational Culture variable (X2) and the OCB (Y) variable is X2.2 Attention to Detail with the Y2 dimension. Conscientiousness is 0.560 and belongs to the medium level of the relationship category. This explains that the dimension X2.2 Attention to Detail in the organizational Culture variable is needed for each increase in OCB (Y), especially in the Conscientiousness dimension. The highest correlation value between the Work Compensation variable (X3) and the OCB (Y) variable is the X3.2 Indirect Compensation dimension with the Y5 dimension. Courtesy is 0.498 and belongs to the medium level of connection category. This explains that the dimension X3.2 Indirect Compensation in the Work Compensation variable is required for each increase in OCB (Y), especially in the Courtesy dimension.

\section{CONCLUSIONS AND RECOMMENDATIONS}

\section{A. Conclusions}

$>$ Transformational leadership partially has a positive and strongly reacted over OCB employees at Judicial Commission environment. Especially the leader is able to provide an ideal influence by being a role model for his subordinates and able to formulate his vision and mission clearly. Besides being able to provide motivation and encourage employees to think innovative. However, leadership is still less attentive to the needs of employees in the process of carrying out tasks.

$>$ Organizational culture partially has a positive and strongly reacted over OCB employees in the Judicial Commission environment, especially the culture of working precisely and accurately and in detail. Besides that, the culture is results-oriented, to individuals, and teams as well as a culture of time discipline and fair competition. However, it is still weak in a sincere culture at work and comfortable at work.

$>$ Compensation has a partially positive and strongly reacted over OCB employees in the Judicial Commission environment, especially compensation does not directly affect the level of employee politeness so as to avoid interpersonal conflict and try to always obey and internalize organizational regulations. However, indirect compensation is still weak to increase enthusiasm and high work commitment.

Transformational leadership, organizational culture, and compensation together have a positive and significant effect on OCB. With a transformational leadership style, strong organizational culture, and high compensation, OCB can improve employees in the Judicial Commission environment.

\section{B. Suggestions}

Based on the above conclusions, the authors provide the following advice:

$>$ Leaders should give limelight to the needs of employees and be able to be a mentor in the process of achieving organizational performance so that employees do not feel when there are obstacles faced in the process of completing tasks become an employee's personal responsibility. With the attention of leadership can foster the voluntary behavior of employees to perform or carry out their duties and obligations more than the target organization.

$>$ Organizations need to maintain the values that already apply in the organization in terms of sincerity at work because work is worship, concern for colleagues who experience or face difficulties in carrying out tasks or personal problems so that employees feel comfortable in working and problems/obstacles that are faced by employees to immediately get a solution and not protracted that can become an iceberg and hinder the achievement of organizational goals. By maintaining organizational values that already exist, it can foster souls. Please help voluntarily fellow colleagues.

$>$ Organizations need to pay attention to the benefits and facilities received by employees fairly and objectively. Employees whose workload is heavier and with good work performance, the benefits received will be different from those that are not heavy, and their work achievements are mediocre so that employees feel their performance is valued more by the organization. With the provision of indirect compensation that is fair and objective, it can foster the voluntary behavior of employees to perform or carry out their duties and obligations more than the organization targets.

$>$ For further research can continue similar research by developing other variables that can affect OCB with a larger population.

\section{REFERENCES}

[1]. Bass, JBernard M., dan JRuth, JBass. (2008). The JBass JHandbook of JLeadership: JTheory, JResearch, and JManagerial Applications. JFree. JNew JYork.

[2]. Budiharjo, A. (2011). JOrganisasi: MenujuJPencapaian KinerjaJOptimum. Jakarta: PrasetyaJMulyaJPublishing.

[3]. Danendra, A.A JNgurahJBagus dan Mujiati, NiJWayan. (2016). JPengaruh JMotivasi, JKompensasi dan JKomitmen OrganisasionalJ TerhadapJ OrganizationalJ CitizenshipJ Behavior (OCB). E-Jurnal JManajemen JUnud, Vol. 5, No. 10, 2016.

[4]. Dessler, Gary. (2016). JManajemen GSumber GDaya Manusia. CetakanGke Dua. Jakarta: SalembaGEmpat.

[5]. Hasibuan, Malayu SP. (2014). ManajemenGSumber DayaGManusia EdisiGRevisi. BumiGAksara. Jakarta. 
[6]. L.

Daft,

Richard.

(2015)

TheGLeadershipGExperience. SixthGEdition. CengageGLearning. Stamford.

[7]. Mamesah, GMarline M. dan GKusmaningtyas, Amiartuti. (2009). "PengaruhG GayaG KepemimpinanG TransformasionalG dan TransaksionalG terhadap KepuasanG GKerja dan DampaknyaG terhadap GKinerja Karyawan”. Jurnal Akuntansi, Manajemen Bisnis dan Sektor Publik. Vol. 5, No. 3, pp. $349-368$.

[8]. PeraturanGMenteri

PendayagunaanGAparaturGNegara dan ReformasiGBirokrasi RepublikGIndonesia GNomor 14 Tahun $2017 \quad$ TentangGPedoman PenyusunanGSurvei KepuasanG GMasyarakat UnitG Penyelenggara PelayananG Publik.

[9]. Robbins dan Coulter. (2016). Manajemen. EdisiGketigabelas. JilidGSatu. Erlangga. Jakarta.

[10]. Robbins, Judge. (2015). PerilakuGOrganisasi. EdisiGEnam Belas. Jakarta: SalembaGEmpat.

[11]. Simamora, Henry. (2010). ManajemenGSumber DayaGManusia. Jakarta: Gramedia.

[12]. Sobihah M. Alsheikh, G.A \& Ayassrah A.Y.A. (2017). AGStudy on theGRelationship betweenGOrganizational Culture, GLeadership GStyle, GOrganizational CommitmentG and OrganizationalG GCitizenship Behaviour, IntrinsicG GMotivation as MediatingGwith Reference to EmployeesGWorking in JordanianGLuxury ClassGHoteL. WorldGApplied SciencesGJournal, December 2017, p.119-126.

[13]. Sudaryono. (2014). BudayaGdan PerilakuGOrganisasi. LenteraGIlmuGCendekia: Jakarta.

[14]. Sutrisno, Edy. (2014). ManajemenGSumber DayaGManusia. CetakGkeGEnam. Jakarta: KencanaGPranada MediaGGroup.

[15]. Tampi, GinaGSheelsia. (2013). KepemimpinanG dan KompensasiGpengaruhnya terhadapGKinerja KaryawanGdan dampaknya terhadapGOrganizational CitizenshipGBaehavior (OCB). Jurnal EMBA, 1(3): 921-929.

[16]. Undang-Undang RepublikGIndonesia Nomor 25 Tahun 2009 TentangGPelayananGPublik.

[17]. Vina S.M., Saudi, M.H.M, Dora Y.M. \& Saudi N.S. (2018) TheGInfluence of TransformationalGLeadership and Employee EngagementGto

OrganizationalGCitizenshipGBehavior (OCB) and theGEffect to DivisionGEffectiveness at PT. $X$ in Indonesia. InternationalGJournal of GEngineering \& Technology (IJET), Volume 7, December 2018, p. 309-313.

[18]. Waspodo GAgung AWS dan Lussy M. (2012). PengaruhGKepuasan KerjaGdan IklimGOrganisasi TerhadapGOrganizational CitizenshipGBehavior (OCB) KaryawanGpada PT. TrubusGSwadaya Depok. Jurnal RisetGManajemen SainsGIndonesia (JRMSI) |Vol. 3, No. 1, 2012. 